Dinamika Kesehatan Jurnal Kebidanan dan Keperawatan Vol 10 No. 1 Juli 2019 (ISSN: 2086-3454 EISSN: 2549-4058)

url: http://ojs.dinamikakesehatan.unism.ac.id DOI : https://doi.org/10.33859/dksm.v10i1

Persepsi Kebutuhan Pendidikan Komunikasi dalam Kesehatan

\title{
Persepsi Kebutuhan Pendidikan Komunikasi dalam Kesehatan
}

Dyan Fitri Nugraha1, Zulliati2, Rian Tasalim3, Noval4, Faisal Rahman5

1,4Program Studi Farmasi Universitas Sari Mulia Banjarmasin

2Program Studi Kebidanan Universitas Sari Mulia Banjarmasin

3Program Studi Ilmu Keperawatan Universitas Sari Mulia Banjarmasin 5Program Studi Pendidikan Bahasa Inggris Universitas Sari Mulia Banjarmasin *correspondence author: Telepon: 0511-3268105, Fax: 0511-3270134, E-mail: dyan.nugraha7@gmail.com

DOI: https://doi.org/10.33859/dksm.v10i1.436

\begin{abstract}
Abstrak
Latar Belakang: Komunikasi efektif menjadi hal penting untuk mencapai tujuan terapi. Komunikasi efektif antar profesi kesehatan dan kepada pasien juga dapat mencegah terjadinya medication error. Tujuan: Penelitian ini bertujuan untuk melihat persepsi kebutuhan pendidikan komunikasi bagi mahasiswa kesehatan serta alasan pentingnya pendidikan komunikasi kesehatan.

Metode: penelitian ini menggunakan Metode survey yang dilaksanakan secara acak kepada 174 responden yang terdiri dari mahasiswa farmasi, keperawatan, dan kebidanan yang sedang/telah menjalani dinas, praktik kerja lapangan atau magang.

Hasil: Hasil penelitian menunjukkan bahwa 99.4\% responden memahami pentingnya ilmu komunikasi namun sebanyak $34.7 \%$ menyatakan masih kurang mendapatkan ilmu komunikasi dalam perkuliahan. Komunikasi dalam kesehatan harus menjadi kemampuan utama dan harus selalu disertai praktik yang memadai sehingga melatih mahasiswa kesehatan untuk dapat berinteraksi dengan baik kepada pasien atau profesi lain.
\end{abstract}

\section{Kata Kunci}

Komunikasi Kesehatan, Komunikasi Efektif 
Dinamika Kesehatan Jurnal Kebidanan dan Keperawatan Vol 10 No. 1 Juli 2019 (ISSN: 2086-3454 EISSN: 2549-4058)

url: http://ojs.dinamikakesehatan.unism.ac.id DOI : https://doi.org/10.33859/dksm.v10i1

Persepsi Kebutuhan Pendidikan Komunikasi dalam Kesehatan

\section{Perception of Communication Education Needs in Health}

Abstract
Background Effective communication has become an important key in achieving the goal of a therapy.
Effective communication, whether it was inter-health proffessions, or between health proffessions and
the patients, were also be able to avoid medication errors.
Objective The objective of this study was to review any perceptions of communication education
needed for health students, plus the reasons why it was necessary.
Methods Methods used in this study was a randomly conducted survey on 174 respondents consisting
of pharmacy, nursing, and midwifery students who were/ had been undergoing any services, field work
practices, or internships.
Results The result of this study showed that $99.4 \%$ of respondents considered communication
education as important, while $34.7 \%$ stated their lacking of communication science in class.
Conclusion Health communication should be the main ability and be accompanied with sufficient
practice, so that it would train health students to interact well both with patients and other health
proffessions.
Key Words
Health Communication, Effective Communication


Dinamika Kesehatan Jurnal Kebidanan dan Keperawatan Vol 10 No. 1 Juli 2019 (ISSN: 2086-3454 EISSN: 2549-4058) url: http://ojs.dinamikakesehatan.unism.ac.id DOI : https://doi.org/10.33859/dksm.v10i1

Persepsi Kebutuhan Pendidikan Komunikasi dalam Kesehatan

\section{Pendahuluan}

Komunikasi adalah jati diri bagi manusia. Melalui komunikasi manusia dapat bertukar informasi dan dapat menjadi cerminan manusia sebagai bagian dari masyarakat sosial dan komunitas (Rimal \& Lapinski, 2009). Tidak hanya sebagai instrumen bersosialisasi, komunikasi juga penting untuk mencapai keberhasilan terapi yang dilakukan oleh tenaga kesehatan. Komunikasi yang efektif serta efisien menjadi tuntutan bagi profesi kesehatan agar tujuan terapi dapat tercapai. Komunikasi yang buruk dapat mengakibatkan hasil yang negatif, seperti terapi yang tidak berjalan semestinya, keamanan bagi pasien dapat terancam, dan terapi serta pengobatan pasien yang tidak efektif sehingga menimbulkan biaya yang lebih banyak (4.9 miliar dollar per tahun) baik bagi instansi kesehatan ataupun pasien (Vermier dkk, 2015).

Pentingnya elemen komunikasi yang perlu diberikan bagi mahasiswa atau siswa kesehatan, membuat pihak penyelenggara pendidikan kesehatan mengajarkan komunikasi dalam kegiatan pembelajaran. Tidak hanya sekedar bisa berbicara dengan pasien atau profesi lain, Mckeever (2014) menyebut bahwa tujuan utama pendidikan komunikasi dalam kesehatan adalah membentuk kemampuan berpikir kritis diikuti meningkatkan kemampuan advokasi.

Namun pertanyaan selanjutnya, apakah materi yang mencakup komunikasi baik kepada pasien atau kepada profesi lain sudah mencukupi? Menjawab pertanyaan tersebut perlu dilakukan survey mengenai persepsi atau pemahaman mahasiswa terhadap ilmu komunikasi yang telah diberikan, serta dampak yang dirasakan mahasiswa setelah mendapakan ilmu komunikasi dalam pendidikan kesehatan ketika berinteraksi dengan pasien atau tenaga kesehatan baik dalam ikatan dinas, magang, ataupun praktik kerja lapangan.

\section{Metode}

Metode yang digunakan dalam penelitian adalah survey persepsi yang dilakukan kepada mahasiswa yang sedang/telah 
Dinamika Kesehatan Jurnal Kebidanan dan Keperawatan Vol 10 No. 1 Juli 2019 (ISSN: 2086-3454 EISSN: 2549-4058) url: http://ojs.dinamikakesehatan.unism.ac.id DOI : https://doi.org/10.33859/dksm.v10i1

Persepsi Kebutuhan Pendidikan Komunikasi dalam Kesehatan

melakukan komunikasi kesehatan kepada

pasien atau tenaga medis lainnya baik dalam

ikatan dinas, magang, ataupun praktik kerja

lapangan. Mahasiswa yang dimaksud dalam

$-1-3$ SKS

$=4-5$ SKS

- 6-7 SKS

$\because 8-9$ SKS

penelitian ini berasal dari jurusan farmasi, keperawatan, dan kebidanan tanpa memperhatikan jenis kelamin dan umur, serta dilakukan secara acak.

\section{Hasil}

Hasil penelitian menunjukkan $99.4 \%$ dari 174 responden menyatakan ilmu komunikasi adalah bagian penting bagi profesi kesehatan. Sebanyak $65.3 \%$ menyatakan sudah cukup mendapatkan mata kuliah terkait komunikasi sementara $34.7 \%$ menyatakan sebaliknya. Responden sejumlah $39.1 \%$ juga menyatakan bahwa mata kuliah terkait komunikasi dalam bangku perkuliahan hanya didapatkan sebanyak 1-3 sks.

\section{Pembahasan}

Hasil penelitian menunjukkan bahwa masih terdapat sepertiga responden yang merasa kurang mendapatkan ilmu komunikasi terkait kesehatan sebagai modal latihan saat berinteraksi dengan pasien atau profesi 
Dinamika Kesehatan Jurnal Kebidanan dan Keperawatan Vol 10 No. 1 Juli 2019 (ISSN: 2086-3454 EISSN: 2549-4058) url: http://ojs.dinamikakesehatan.unism.ac.id DOI : https://doi.org/10.33859/dksm.v10i1

Persepsi Kebutuhan Pendidikan Komunikasi dalam Kesehatan

kesehatan lainnya. Berdasarkan deskripsi kualitatif yang dinyatakan oleh responden, penting untuk tidak hanya sekedar memberikan materi terkait komunikasi, melainkan juga praktik dalam melakukan komunikasi yang baik, benar, dan efisien. Mengingat dampak negatif yang dapat dirasakan oleh responden bila tidak mendapatkan ilmu komunikasi dapat berakibat fatal, seperti pesan yang tidak tersampaikan dengan baik yang menyebabkan resiko terjadinya medication error hingga berakibat kematian bagi pasien.

Sebagai tenaga medis, kematian akibat medication error tidak hanya memberikan kerugian besar bagi pasien dan keluarga, namun juga bagi pihak instansi penyelenggara kesehatan seperti rumah sakit. Mengutip penelitian Vozikis dkk (2016) menyebutkan bahwa kematian adalah faktor paling banyak mengeluarkan biaya akibat medication error. Dirinya juga menyebutkan bahwa angka kematian akibat medication error di Britania Raya sebanyak 20.000-30.000 orang per tahun.

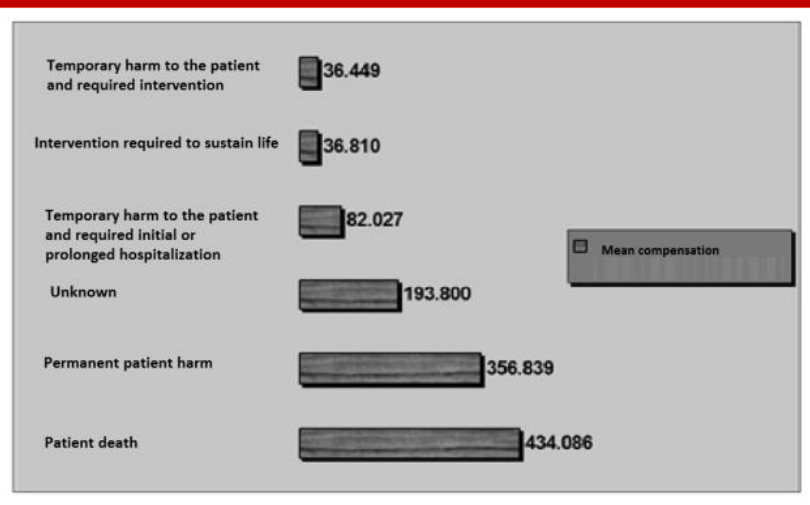

Gambar2. Rata-rata kompensasi yang diberikan dalam $€$

Terlepas apa yang menjadi penyebab medication error, penting untuk meminimalisir terjadinya kejadian medication error salah satunya adalah dengan meningkatkan kemampuan komunikasi para tenaga kesehatan. Pendekatan interprofesi secara edukasi ataupun kolaborasi dalam pendidikan dapat menjadi jalan keluar terbaik untuk mempersiapkan tenaga kesehatan, karena melatih para calon tenaga kesehatan untuk berkomunikasi sesuai dengan kemampuan dan batasan profesi masing-masing serta menyadari pentingnya kerjasama antar profesi untuk mencapai tujuan terapi. 
Dinamika Kesehatan Jurnal Kebidanan dan Keperawatan Vol 10 No. 1 Juli 2019 (ISSN: 2086-3454 EISSN: 2549-4058)

url: http://ojs.dinamikakesehatan.unism.ac.id DOI : https://doi.org/10.33859/dksm.v10i1

Persepsi Kebutuhan Pendidikan Komunikasi dalam Kesehatan

\section{Ucapan Terima Kasih}

Terimakasih kepada Tuhan Yang Maha

Esa, keluarga dan kolega serta Universitas Sari

Mulia sehingga penelitian ini bisa terlaksana.

Semoga bisa memberikan manfaat bagi

siapapun yang membacanya.

\section{Daftar Pustaka}

Meckeever B. W., 2014. The Status of Health Communication: Education and Employment Outlook for a Growing Field. Journal of Health Communication: International Perspectives. 19:12, 1408-1423.

Rimal, R.N \& Lapinski, M.K. 2009. Why health communication is important in public health. Bulletin of the World Heatlh Organization. 87:247

Vermier P., Vandijck D., Degroote S., Peleman R., Verhaeghe R., Mortier E., Hallaert G., Van Daele S., Buylaert., W., Vogelaers D. 2015. Communication in healthcare: a narrative review of the literature and practical recommendations. International Journal of Clinical Practice 69(11):1257-1267.

Vozikis, A., Riga, M., Pollalis Y. 2016. Medical Malpractice Risk Factors: An Economic Perspective of Closed Calims Experience. Bulletin of the World Heatlh Organization. 87:247 